\title{
Analgosedation in paediatric severe traumatic brain injury (TBI): practice, pitfalls and possibilities
}

\author{
N. Ketharanathan ${ }^{1,2}$ (D) Y. Yamamoto ${ }^{3}$ - U. Rohlwink ${ }^{4}$ - E. D. Wildschut ${ }^{1}$. \\ M. Hunfeld ${ }^{1}$ - E.C.M. de Lange $^{3} \cdot$ D. Tibboel ${ }^{1}$
}

Received: 28 June 2017 / Accepted: 29 June 2017

(C) The Author(s) 2017. This article is an open access publication

\begin{abstract}
Analgosedation is a fundamental part of traumatic brain injury (TBI) treatment guidelines, encompassing both first and second tier supportive strategies. Worldwide analgosedation practices continue to be heterogeneous due to the low level of evidence in treatment guidelines (level III) and the choice of analgosedative drugs is made by the treating clinician. Current practice is thus empirical and may result in unfavourable (often hemodynamic) side effects. This article presents an overview of current analgosedation practices in the paediatric intensive care unit (PICU) and addresses pitfalls both in the short and long term. We discuss innovative (pre-)clinical research that can provide the framework for initiatives to improve our pharmacological understanding of analgesic and sedative drugs used in paediatric severe TBI and ultimately facilitate steps towards evidence-based and precision pharmacotherapy in this vulnerable patient group.
\end{abstract}

Keywords Traumatic brain injury $\cdot$ Paediatric $\cdot$ Analgesia $\cdot$ Sedation $\cdot$ Pharmacology

N. Ketharanathan

n.ketharanathan@erasmusmc.nl

1 Intensive Care and Department of Paediatric Surgery, Erasmus Medical Center, Sophia Children's Hospital, Rotterdam, The Netherlands

2 Erasmus MC-Sophia Children's Hospital, PO Box 2060, 3000 CB Rotterdam, The Netherlands

3 Leiden Academic Center for Drug Research, University of Leiden, Leiden, The Netherlands

4 Division of Neurosurgery, Red Cross War Memorial Children's Hospital, University of Cape Town, Cape Town, South Africa

\section{Introduction}

The main goal of (paediatric) TBI treatment is the provision of supportive care to guarantee adequate cerebral perfusion to meet cerebral metabolic demands and limit secondary brain injury $[1,2]$. Appropriate management is critical as paediatric TBI still causes major morbidity and mortality worldwide [3, 4]. One of the cornerstones in severe paediatric TBI treatment is providing analgesia and sedation; however, current research efforts have not provided any level 1 evidence to support a specific regimen. This has resulted in the international 2012 TBI guideline recommendation that: 'the choice of and dosing of sedative, analgesics .... should be left to the treating physician..' [5]. This leads to heterogeneous analgosedation prescribing practices based on local expertise and guided by (hemodynamic) side effects which can lead to both over and under sedation. Furthermore, it seems that exposure to certain analgosedation drugs might lead to neurotoxic injury and could be associated with unfavourable outcome in the long term (e.g. radiographic decrease in brain mass, learning disabilities), especially in the developing paediatric patient [6-8]. Although it is difficult to differentiate between the sequelae of primary vs. secondary brain injury, such observations necessitate better pharmacological understanding to achieve both effective and safe analgesia and sedation. To that end, it is important to gain insight into the pharmacokinetics (PK; i.e. 'what the body does to the drug') and the resulting pharmacodynamics (PD; i.e. 'what the drug does to the body') of frequently used analgosedative drugs. It should be noted that plasma PK may differ substantially from brain target site PK due to the functionalities of the blood-brain-barrier (BBB) and the blood-cerebrospinal fluid barrier (BCSFB) [9] and information on drug target site distribution is essential to understand PK-PD relationships in different TBI disease states. Collaboration between preclinical and clinical research is 
essential in this respect. Techniques such as high-frequency multimodal neuromonitoring, including cerebral microdialysis, combined with advanced PK-PD modelling are promising tools $[10,11]$. The physiologically based (PB) pharmacokinetic (PBPK) modelling approach is particularly useful as it allows translation from animals to humans. Measurements that cannot be performed (or only highly limited) in humans can be performed in animals, and the resulting data can be physiologically scaled to predict PK in humans. This is imperative to fully understand how drugs behave in the body and vice versa. This improved pharmacological understanding will facilitate development of more patient-specific treatment strategies in a heterogeneous condition like paediatric TBI, which requires a tailored approach to achieve effective and safe therapy. This narrative review aims to provide an overview of current practice and its potential pitfalls and discusses possibilities of developing more evidence-based analgosedation practices in paediatric TBI.

\section{Methods}

A literature search was performed using search strategies with MeSH terms and synonyms of 'brain injury', 'analgesia', 'sedation' and 'children' with the search databases Embase, Ovid, Cochrane Central, Web of Science and Google Scholar. A total of 1160 potential references were found that were reviewed by the primary author for relevance based on the aim to provide a pharmacological overview of paediatric severe TBI analgosedation practice and principles. Additional references were added by cross-reference check. It must be emphasized that the 2012 international guidelines for paediatric TBI management remain the mainstay of treatment recommendations [5]. This article provides additional pharmacological background information and highlights novel approaches in pharmacological research.

\section{Practice}

The application of analgesia and sedation in the stabilisation and (supportive) treatment of paediatric severe TBI occurs in various settings from the scene of the accident, emergency department, perioperatively and after admission and stay in the paediatric intensive care unit (PICU). The primary aim for administering analgosedation is to lower cerebral metabolic demand which can be increased by anxiety, stress and pain induced by the primary trauma and further exacerbated by noxious stimuli such as (invasive) procedures and invasive ventilation [2, 12-14]. This article will focus on analgosedation practices in the PICU. The ideal properties of analgosedation drugs in paediatric severe TBI would be to induce an immediate analgesic and/or sedative effect without negatively affecting hemodynamic stability or intracranial pressure (ICP) and have rapid offset of action to enable neurological examination. The compound should also be safe in the long term with respect to neurotoxicity. Many frequently used compounds offer some of the aforementioned characteristics, but none have so far demonstrated all favourable elements. Perhaps, this is not possible given the physiological and developmental differences between patients from ages 0 to 18 years and the heterogeneous nature of brain injury itself.

Most PICUs adopt a TBI protocol based on international guidelines, consensus and local variations in practice. The provision of sedation and analgesia is subdivided in socalled first and second tier therapies in a step-up approach to control ICP and maintain adequate cerebral perfusion pressure (CPP) $[5,15]$. Adherence to local protocols with respect to analgosedation varies based on personal preference and patient-specific factors. A survey in the USA explored physician agreement with published recommendations and guidelines for paediatric TBI showed a $91 \%$ agreement with firsttier sedation recommendations and a $89 \%$ agreement with the use of barbiturates as second tier therapy. However, no specification was provided as to which agents were used when providing analgosedation [16]. One study, which audited its analgosedation practice, reported a $64 \%$ adherence to their written protocol with patient-specific adjustments in $30 \%$ of these cases [17]. This illustrates the variation in analgosedation practice for paediatric TBI, which is not surprising given the lack of evidence-based regimen.

Analgesic compounds described in the literature for paediatric severe TBI are opioids (Fentanyl, Remifentanil, Morphine), Acetaminophen and Metamizole [12, 17-20]. Sedative compounds include benzodiazepines (Midazolam, Lorazepam, Diazepam), Ketamine, Propofol, Dexmedetomidine and Etomidate [12, 14, 17, 18, 21]. Barbiturates (Thiopental and Pentobarbital) are part of second tier therapeutic strategies for lowering refractory intracranial hypertension under electroencephalogram (EEG)-monitoring to ascertain burst-suppression [2, 12, 14, 18, 22-24]. Tables 1 and 2 provide an overview of the pharmacological properties of the various analgosedative drugs (only Food and Drug Administration (FDA) approved drugs included).

Most commonly, a combination of an analgesic and sedative drug is prescribed as a continuous infusion with a step-up approach in dosing based on clinical effect (often a combination of neurological exam, ICP-threshold, and pain and sedation scoring systems). The sedative effect of most analgesic compounds during dose escalation is often an added benefit in ICP control [14]. Additional bolus medication is common to combat prolonged ICP elevation and determine if pain could be a possible cause thereof [14]. Reports indicate that Fentanyl and Midazolam (separately or in conjunction) are mostly used as bolus analgosedation. Various studies have been performed to clarify which bolus medications are most effective to lower high ICP 
Table 1 Overview analgesic drugs in paediatric severe traumatic brain injury

\begin{tabular}{|c|c|c|c|c|c|c|}
\hline Class & Medication & Mode of action & Dosage & $\mathrm{T} 1 / 2$ & Side effects & PK points of interest \\
\hline \multirow[t]{7}{*}{ Opioid } & \multirow[t]{3}{*}{ Morphine } & \multirow[t]{3}{*}{ Opiate receptor agonist } & $\begin{array}{l}\text { Bolus } 0.05-0.1 \\
\quad \mathrm{mg} / \mathrm{kg}\end{array}$ & \multirow[t]{3}{*}{$2-4 \mathrm{~h}$} & \multirow[t]{3}{*}{$\begin{array}{l}\text { Respiratory depression, } \\
\text { hypotension, urinary } \\
\text { retention, vomiting, } \\
\text { constipation, pruritus }\end{array}$} & $\begin{array}{l}\text { Active metabolite } \\
\text { morphine-6-glucuronide (M6G) }\end{array}$ \\
\hline & & & \multirow[t]{2}{*}{$\begin{array}{l}\text { Range } 0.01-0.04 \\
\quad \mathrm{mg} / \mathrm{kg} / \mathrm{h}\end{array}$} & & & $\begin{array}{l}\text { Direct interaction with opioid binding } \\
\text { sites in brain }\end{array}$ \\
\hline & & & & & & $\begin{array}{l}\text { Active efflux mechanism in brain } \\
\text { (P-glycoprotein and multidrug } \\
\text { resistance-associated protein } \\
\text { (MRP)) and active influx transporter } \\
\text { (undefined) }\end{array}$ \\
\hline & \multirow[t]{2}{*}{ Fentanyl } & \multirow[t]{2}{*}{$\begin{array}{l}\text { Opiate receptor } \\
\text { agonist: inhibition } \\
\text { of nociceptive } \\
\text { neurotransmitters }\end{array}$} & $\begin{array}{r}\text { Bolus } 1-2 \\
\mathrm{mcg} / \mathrm{kg}\end{array}$ & \multirow[t]{2}{*}{$7 \mathrm{~h}$} & \multirow[t]{2}{*}{$\begin{array}{l}\text { Sedation, respiratory } \\
\text { depression, } \\
\text { hypotension, muscle } \\
\text { rigidity (thorax), nausea }\end{array}$} & \multirow[t]{2}{*}{$\begin{array}{l}\text { High lipophilicity leading to easier } \\
\text { penetration CNS. Not subjected to } \\
\text { active transport across the BBB }\end{array}$} \\
\hline & & & $\begin{array}{l}\text { Range } 1-2 \\
\mathrm{mcg} / \mathrm{kg} / \mathrm{h}\end{array}$ & & & \\
\hline & \multirow[t]{2}{*}{ Remifentanil } & $\begin{array}{l}\text { Opiate (specific) } \\
\text { mu-receptor agonist }\end{array}$ & $\begin{array}{l}\text { Bolus } 0.25-1 \\
\quad \mathrm{mcg} / \mathrm{kg}\end{array}$ & \multirow[t]{2}{*}{$1-20 \mathrm{~min}$} & \multirow[t]{2}{*}{$\begin{array}{l}\text { Respiratory depression, } \\
\text { muscle rigidity, } \\
\text { hypotension, nausea, } \\
\text { pruritus }\end{array}$} & \multirow[t]{2}{*}{$\begin{array}{l}\text { Direct interaction with opioid binding } \\
\text { sites in brain }\end{array}$} \\
\hline & & $\begin{array}{l}\text { Ultra-rapid onset and } \\
\text { offset of action }\end{array}$ & $\begin{array}{l}\text { Range } 0.1-2 \\
\mathrm{mcg} / \mathrm{kg} / \mathrm{min}\end{array}$ & & & \\
\hline \multirow[t]{2}{*}{ Other } & \multirow[t]{2}{*}{ Acetaminophen } & $\begin{array}{l}\text { Inhibition of } \\
\text { cyclooxygenase } \\
\text { (COX) enzymes } \\
\text { involved in } \\
\text { prostaglandin } \\
\text { synthesis }\end{array}$ & $\begin{array}{l}\text { Loading dose } \\
\qquad 20 \mathrm{mg} / \mathrm{kg} \text { i.v. }\end{array}$ & \multirow[t]{2}{*}{$1-4 \mathrm{~h}$} & \multirow[t]{2}{*}{$\begin{array}{l}\text { Risk of hepatic necrosis } \\
\text { and failure in } \\
\text { prolonged or high } \\
\text { dosage }\end{array}$} & \multirow[t]{2}{*}{ Blockage of COX enzymes in the CNS } \\
\hline & & & $\begin{array}{l}\text { Maintenance } \\
60 \mathrm{mg} / \mathrm{kg} / \mathrm{dg} \\
\text { in } 4 \text { doses } \\
\text { (maximum } \\
1 \text { g per dose) }\end{array}$ & & & \\
\hline
\end{tabular}

The abovementioned dosage suggestions are for children aged $0-18$ years of age, with the exception of neonates $(<1$ month old)

$B B B$ blood-brain-barrier, $C O X$ cyclooxygenase, $C N S$ central nervous system, i.v. intravenous, $M R P$ multidrug resistance-associated protein, $P K$ pharmacokinetic

and present conflicting and sometimes paradoxical results [25]. The benefit of Ketamine for episodic use during potential noxious stimuli (e.g. endotracheal tube suctioning) is that it does not decrease blood pressure and could be a valuable adjuvant for interventions [26]. However, historically, this compound has been avoided as it was associated with an increase in ICP [27-29]. Recent paediatric studies using (racemic) Ketamine as bolus medication for episodes of sustained ICP elevation demonstrate its effect in lowering intracranial hypertension [18]. Adult studies show similar findings and support its use when combined with Midazolam [30]. Remifentanil has been shown to be an effective analgesic drug (mostly demonstrated in the adult critical care setting) due to its rapid onset and offset of action enabling frequent, serial neurological examinations [19, 20, 31]. Barbiturates (Thiopentone and Pentobarbital) are implemented as second tier therapy to control refractory intracranial hypertension and have been shown to be effective in reducing
ICP in the paediatric population in $30-52 \%$ of patients [23, 32]. Dexmedetomidine is gaining increasing interest as a sedative agent in the PICU due to its limited side effects although the majority of publications are based on postoperative cardiac patients. It has been approved by the FDA for sedation $<24 \mathrm{~h}$ in adults with invasive ventilation and there are reports of its use in the PICU for severe TBI patients (who went on to have good neurological outcomes) and it has been reported to have a opioidsparing effect in PICU patients requiring sedation [21, 33]. Finally, a brief word on neuromuscular blockade (NMB) is warranted as this is combined with analgosedation in first-tier strategies to reduce energy expenditure (e.g. shivering) and improve mechanical ventilation synchronization. Again no class I evidence for NMB is available but it is imperative that at the same time continuous electroencephalography is implemented when continuous NMB infusion is used to determine the presence of posttraumatic seizures $[5,14,34]$. 
Table 2 Overview sedative drugs in paediatric severe traumatic brain injury

\begin{tabular}{|c|c|c|c|c|c|c|}
\hline Class & Medication & Mode of action & Dosage & $\mathrm{T} 1 / 2$ & Side effects & $\begin{array}{l}\text { PK points of } \\
\text { interest }\end{array}$ \\
\hline \multirow[t]{2}{*}{ Benzodiazepine } & Midazolam & $\begin{array}{l}\text { GABA receptor } \\
\text { agonist }\end{array}$ & $\begin{array}{l}\text { Bolus } \\
\quad 0.05-0.2 \\
\mathrm{mg} / \mathrm{kg}\end{array}$ & $\begin{array}{l}5.5 \mathrm{~h} \\
\quad( \pm 3.5 \mathrm{~h})\end{array}$ & $\begin{array}{l}\text { Sedation, respiratory } \\
\text { depression, } \\
\text { hypotension, } \\
\text { bradycardia, } \\
\text { (paradoxical) } \\
\text { emergence delirium }\end{array}$ & $\begin{array}{l}\text { Metabolized to } \\
\text { active } \\
\text { metabolites } \\
\text { 1- and } \\
\text { 4-hydroxy- } \\
\text { midazolam }\end{array}$ \\
\hline & & & $\begin{array}{l}\text { Range } \\
0.05-0.5 \\
\mathrm{mg} / \mathrm{kg} / \mathrm{h}\end{array}$ & & & Lipophilic \\
\hline \multirow[t]{3}{*}{ Barbiturate } & Pentobarbital & $\begin{array}{l}\text { GABA receptor } \\
\text { agonist }\end{array}$ & Bolus $5 \mathrm{mg} / \mathrm{kg}$ & $\begin{array}{l}5-50 \mathrm{~h} \text { (dose } \\
\text { dependant) }\end{array}$ & $\begin{array}{l}\text { Sedation, respiratory } \\
\text { depression, } \\
\text { hypotension, } \\
\text { laryngospasm, } \\
\text { anaphylactic } \\
\text { reactions have } \\
\text { been reported }\end{array}$ & Lipophilic \\
\hline & & & $\begin{array}{l}\text { Range } \\
\qquad 1-2 \mathrm{mg} / \mathrm{kg} / \mathrm{h}\end{array}$ & & & \\
\hline & Thiopental & $\begin{array}{l}\text { GABA receptor } \\
\text { agonist }\end{array}$ & $\begin{array}{l}\text { Range } \\
12,5 \mathrm{mg} / \mathrm{kg} / \mathrm{h} \\
\text { (starting dose } \\
\text { for } 6 \mathrm{~h} \text { ), then } \\
5 \mathrm{mg} / \mathrm{kg} / \mathrm{h} \\
\text { and taper to } \\
3 \mathrm{mg} / \mathrm{kg} / \mathrm{h} \\
\text { depending } \\
\text { on EEG and } \\
\text { plasma } \\
\text { concentration }\end{array}$ & $3-8 \mathrm{~h}$ & $\begin{array}{l}\text { Sedation, respiratory } \\
\text { depression, } \\
\text { hypotension, skin } \\
\text { reactions (due to } \\
\text { histamine release), } \\
\text { laryngo- and } \\
\text { bronchospasm }\end{array}$ & Lipophilic \\
\hline \multirow[t]{5}{*}{ Other } & Propofol & $\begin{array}{l}\text { GABA receptor } \\
\text { agonist }\end{array}$ & Bolus $1-2 \mathrm{mg} / \mathrm{kg}$ & $\begin{array}{l}\text { 2-10 min } \\
\text { (initial } \\
\text { distribution } \\
\text { phase) }\end{array}$ & $\begin{array}{l}\text { Hypotension, } \\
\text { respiratory } \\
\text { depression, } \\
\text { hypertriglyceridemia, } \\
\text { PRIS }\end{array}$ & Lipophilic \\
\hline & & & $\begin{array}{l}\text { Range (not } \\
\text { recommended } \\
\text { but reported } \\
\text { up to } 4 \\
\mathrm{mg} / \mathrm{kg} / \mathrm{h})\end{array}$ & & & \\
\hline & Dexmedetomidine & $\begin{array}{l}\text { Selective } \\
\text { alpha-2-adrenoreceptor } \\
\text { agonist }\end{array}$ & $\begin{array}{l}\text { Range } 0.1-2 \\
\mathrm{mcg} / \mathrm{kg} / \mathrm{h} \\
\text { (loading dose } \\
0.25 \mathrm{mcg} / \mathrm{kg} \\
\text { optional) }\end{array}$ & $2 \mathrm{~h}$ & $\begin{array}{l}\text { Hypertension, } \\
\text { bradycardia }\end{array}$ & Lipophilic \\
\hline & Ketamine & $\begin{array}{l}N \text {-methyl-D-aspartate } \\
\text { receptor antagonist }\end{array}$ & $\begin{array}{c}\text { Bolus 1-2 } \\
\mathrm{mg} / \mathrm{kg}\end{array}$ & $2.5-3 \mathrm{~h}$ & $\begin{array}{l}\text { Laryngospasm, } \\
\text { tachycardia, } \\
\text { dysphoria }\end{array}$ & Lipophilic \\
\hline & Etomidate & $\begin{array}{l}\text { GABA receptor } \\
\text { agonist }\end{array}$ & $\begin{array}{l}\text { Bolus } 0.3-0.5 \\
\text { mg } / \mathrm{kg}\end{array}$ & $75 \mathrm{~min}$ & $\begin{array}{l}\text { Adrenal insufficiency, } \\
\text { hypertension, } \\
\text { laryngospasm, } \\
\text { dyskinesia }\end{array}$ & Lipophilic \\
\hline
\end{tabular}

The abovementioned dosage suggestions are for children aged $0-18$ years of age, with the exception of neonates $(<1$ month old)

$E E G$ electroencephalogram, GABA gamma-aminobutyric acid, $P K$ pharmacokinetic, $P R I S$ propofol infusion syndrome

At this point, it needs to be noted that 'efficacy' of analgosedation is often titrated solely on the effect of ICPand CPP-control and clinical signs of agitation. However, there is increased awareness that there are additional factors which need to be considered to develop a holistic picture of risk factors for secondary injury that could serve as pharmacodynamic (PD) markers in analgosedation studies. Multimodal neuromonitoring seems especially important 
when defining clinical parameters of therapeutic efficacy. PD markers of effective drug therapy could include cerebral oxygenation $(\mathrm{PbtO} 2)$, cerebral metabolic state (cerebral microdialysis yielding information on lactate and pyruvate) and brain activity as monitored by continuous electroencephalogram (EEG) [10]. Furthermore, it might be beneficial to differentiate between patients with or without intact cerebral autoregulation as certain drugs could actually induce an ICP increase (and CPP decrease) when cerebral autoregulation is preserved $[35,36]$. In this respect, the time from initial injury can also be an important factor, resulting in a different response of the brain to analgosedative drugs over time.

\section{Pitfalls}

The potential negative effects of commonly used analgosedative drugs can be subdivided into short- and longterm pitfalls. Short-term pitfalls mostly refer to undesirable hemodynamic side effects, i.e. a decrease in mean arterial blood pressure (MAP) resulting in a decrease in cerebral perfusion pressure (CPP), which can further exacerbate secondary brain injury. Potential pitfalls based on specific drug or patient characteristics are summarized in the following paragraph. A more extensive overview of side effects is provided in Tables 1 and 2.

Continuous infusion of Propofol is associated with Propofol infusion syndrome (PRIS), which is characterized by the onset of metabolic acidosis, rhabdomyolysis, acute renal failure, cardiac dysthythmias and hyperlipidemia [37, 38]. Although there is evidence that continuous Propofol infusion $<4 \mathrm{mg} / \mathrm{kg} / \mathrm{h}$ for periods $>48 \mathrm{~h}$ can be safe $[39,40]$, the cost-oferror is deemed so great that the FDA recommends withholding from continuous Propofol infusion in paediatric TBI [41]. As for bolus medication, Propofol is sometimes briefly used as an adjuvant for procedural sedation. However, it is noteworthy that delayed posttrauma administration of Propofol could be associated with induction of apoptosis due to increased expression of the P75 neurotrophin receptor, sensitizing the brain for neurotoxic effects in juvenile neurons [42]. Etomidate could be useful as bolus therapy for intracranial hypertension episodes due to its favourable hemodynamic profile [43]; however, its use is often restricted to intubation settings due to the association with adrenal insufficiency [2]. Thiopental can potentially cause life-threatening electrolyte imbalances, especially regarding potassium [44]. Dexmedetomidine has been reported to induce hypertension at high-dose infusion ( $>4 \mu \mathrm{g} / \mathrm{kg} / \mathrm{h}$ ) for several hours [45]. Other reports have noted the occurrence of bradycardia, which is more pronounced when this agent is combined with other medications that yield a negative chronotropic effect [21]. Metamizole is frequently used as a non-opioid first-line analgesic for adults in many countries but there are still many controversies about potential risks (like agranulocytosis), leading to a ban by the FDA. A recent systematic review and meta-analysis showed that Metamizole is safe (no reports of agranulocytosis) for short-term use in hospital [46]. Although its role in paediatric analgesia is unclear, it is reportedly used in certain countries [17]. Various studies have demonstrated that opioids could potentially increase ICP in TBI patients with preserved cerebral autoregulation in conjunction with systemic effects of mean blood pressure decrease. This effect was most pronounced for Fentanyl [36, 47]. Furthermore, a recent study on the effectiveness of pharmacological therapies for intracranial hypertension demonstrated that Fentanyl was significantly associated with frequent treatment failure when compared to Pentobarbital and hypertonic saline [48]. Fentanyl and Midazolam as bolus therapies for intermittent intracranial hypertension have been associated with ICP increase and CPP reduction [35].

Spreading depolarizations present a potential threat to functional neurons, resulting in necrosis or degeneration and possibly poor outcome after brain injury. Analgosedation acts by influencing neuronal homeostasis and has been investigated for preventing or propagating spreading depolarizations. One study found that $N$-methyl-D-aspartate (NMDA) receptor agonists (such as Ketamine) led to less spreading depolarizations, but Midazolam increased the amount of spreading depolarization clusters. These findings need to be investigated further but provide an interesting angle into pitfalls and possibilities of these drugs [49]. Finally, it must be emphasized that the severe TBI patient is often subject to polypharmacy (i.e. multiple drugs being prescribed concurrently). It is important to be aware of drug-drug-interactions, which can lead to subsequent undesirable effects. For example, the protonpump inhibitor Esomeprazole is frequently prescribed in critically ill patients. It has been reported that prescribing Esomeprazole increases the volume of distribution and halflife of Thiopentone, which needs to be taken into account when aiming for certain target concentrations [50].

Long-term pitfalls have been described in the context of (major) withdrawal symptoms and delirium, which obscure adequate neurological evaluation. This suggests not only the need for dose escalation in the acute phase of patient stabilisation but also the development of guidelines to optimally taper analgosedation afterwards [51]. Validated tools to assess withdrawal symptoms (which can already occur after 5 consecutive days of opioid and/or benzodiazepine administration) and delirium in the PICU are the Withdrawal Assessment Tool version 1 (WAT-1) and Sophia Observation withdrawal Symptoms-Paediatric Delirium scale (SOS-PD) [52, 53].

Pharmacogenetics can be considered part of patientspecific pitfalls. Important examples are so-called ABCB1 polymorphisms, which encode for P-glycoprotein transporter that is responsible for morphine efflux over the blood-brain barrier. This can result in different cerebral morphine 
concentrations and associated (prolonged) effect. The latter has mostly been investigated in the context of prolonged respiratory depression after opioid administration during elective procedures $[54,55]$.

Finally, there are concerns about the potential neurotoxic apoptotic effects of certain drugs, especially in the developing brain. Animal studies have demonstrated mechanisms by which analgosedative agents of different classes (which are also used in the PICU for TBI) trigger upregulation of apoptotic cerebral cascades (i.e. blocking of glutamate NMDA receptors, activation of gamma-aminobutyric acid (GABA), receptors or blocking of voltage gated sodium channels). This results in inactivation of cell survival signalling proteins and activation of inflammatory cytokines [7]. Furthermore, anaesthetic opioid exposure in animals showed a possible neurotoxic effect as demonstrated by elevated levels of S100B, a biomarker of brain injury [56]. It is of interest that these effects in animals and cultured neuronal cells were dose dependant and dependant on the maturity of neuronal tissue [57]. Studies in preterm infants exposed to Fentanyl suggest that a higher cumulative dose correlated with an increased incidence of cerebellar injury and lower cerebellar size when compared at term equivalent age [6]. However, the results from paediatric general anaesthesia studies evaluating long-term neurodevelopmental outcome are more difficult to interpret as these are heterogeneous populations often with a preexisting condition (e.g. congenital defect) giving rise to an a priori increased risk of deficits in neurological development $[8,58]$. Of course extrapolation of preclinical and paediatric anaesthetic clinical study findings to analgosedation practices in paediatric TBI should be done with caution, despite the use of similar compounds. However, these observations are important as they emphasise the necessity to search for both effective and safe analgosedation dosing strategies in paediatric TBI.

\section{Possibilities}

To date, current approaches have not been able to conclusively yield the desired answers, i.e. which drugs are safe and effective to prescribe in (paediatric) TBI? The high failure rate in CNS drug development and research can in part be attributed to the fact that 'golden standard' approaches, such as randomized controlled trials (RCTs) and comparative effectiveness designs, fail to take into account the heterogeneity of the disease process and drug- and patient-specific characteristics. In particular, the unique functionality of the blood-brain and blood-cerebrospinal (CSF) barrier, and therewith drug transport into and out of the brain, are not elucidated. Thus, drug target site concentration (e.g. cerebral drug concentrations) are unknown. Information on the target site concentrations is fundamental in understanding drug action. Therefore, assessing target site pharmacokinetics is the primary step before attempting to study the resulting pharmacodynamics $[9,11$, 59].

Bottlenecks in pharmacological research, especially in children, are ethical concerns about performing invasive studies of compounds with unproven benefit in minors, and difficulty obtaining adequate sample size to provide definitive answers. Another obstacle in paediatric drug research is the limited number and volume of blood or cerebral fluid samples which can be obtained per patient due to smaller circulating volumes. This is where 'bench-meets-bedside' research can be of value. Animal-based PBPK models can be translated to humans and thereby serve as templates of what happens to a drug in the body under various clinical conditions. After translation of the animal PBPK model to humans, full drug concentration PK profiles in human brain can be predicted. The PBPK human model can be validated by comparing predicted drug concentration values to a number of observed drug concentrations in the human CNS (e.g. CSF and brain extracellular fluid from microdialysis monitoring). Especially for paediatric PK analysis, obtaining individual plasma PK is crucial to predict a drug concentration time profile in the CNS due to the various developmental differences that have an impact on PK profiles. Collecting sufficient human samples can be challenging, but 'sparse sampling population-based PK (PPK) analysis' is an innovative statistical technique that can be used to solve this challenge. Practically, this model requires only a limited number of samples per patient. The samples of various patients are then used as a single 'population' (after corrections of covariates such as age, weight, renal function) providing enough data points to compile drug-specific pharmacokinetic time profiles under different clinical conditions and developmental differences. In other words, the combination of PBPK and PPK modelling allows prediction of drug concentrations at various target sites (e.g. blood plasma, brain extracellular fluid) at different dosing regimens for each paediatric patient. It has been enlightening that drug plasma concentrations do not represent cerebral drug concentrations, highlighting the unique properties of the blood-brain and blood-cerebrospinal fluid barrier [11, 59-61].

Although focus must shift 'back to basics' with regard to improved pharmacological understanding of frequently used analgesics and sedatives, this does not mean observations from the clinical field should be dismissed. For example, comparative effectiveness research could provide direction as to which drug compounds warrant further PK-PD research. Finally, pharmacology is dynamic, complicated and an indispensable part of clinical practice. It is imperative we understand basic principles but also cooperate with experts in the field to optimize our treatment. In this respect, a clinical pharmacologist or hospital pharmacist can be of great value to point out significant drug interactions and provide alternative options as well as dose adjustments based on clinical status. It 
is becoming increasingly clear that a multifactorial, complex disease like (paediatric) severe TBI warrants a multidisciplinary approach, also as regards pharmacology.

\section{Conclusion}

Analgosedation is a crucial part of severe (paediatric) TBI management but evidence-based guidelines are not available leaving the choice of analgesic and sedative drugs to the treating physician. Practice is heterogeneous and leads to serious concerns about efficacy and safety. Pitfalls, besides the well-known side effects of frequently used drugs, include paediatric-specific concerns in terms of potential neurotoxicity in the developing brain and age-specific differences in drug distribution and metabolism. Possibilities to enhance our pharmacological understanding include the implementation of animal-based pharmacokinetic models that enable prediction of drug concentrations at target sites. This combined with multimodal neuromonitoring can link cerebral drug concentrations to drug effect and ultimately lead to more evidencebased analgosedation therapies in (paediatric) TBI.

Acknowledgements The authors would like to thank the Biomedical Information Specialist(s) of the Medical Library of Erasmus Medical Center, Gerdien B. de Jonge and Wichor M. Bramer, for their assistance in the literature search.

\section{Compliance with ethical standards}

Conflict of interest No conflict of interest to declare.

Funding N. Ketharanathan received research funding from Sophia Children's Hospital Research Fund (SSWO).

Open Access This article is distributed under the terms of the Creative Commons Attribution 4.0 International License (http:// creativecommons.org/licenses/by/4.0/), which permits unrestricted use, distribution, and reproduction in any medium, provided you give appropriate credit to the original author(s) and the source, provide a link to the Creative Commons license, and indicate if changes were made.

\section{References}

1. Jagannathan J, Okonkwo DO, Hian KY, Dumont AS, Saulle D, Haizlip J et al (2008) Long-term outcomes and prognostic factors in pediatric patients with severe traumatic brain injury and elevated intracranial pressure: clinical article. J Neursurg Pediatr 2(4):240 249

2. Kochanek PM, Carney N, Adelson PD, Ashwal S, Bell MJ, Bratton $S$ et al (2012) Guidelines for the acute medical management of severe traumatic brain injury in infants, children, and adolescents - second edition. Pediatr Crit Care Med 13(Suppl 1):S1-82

3. Mazzola CA, Adelson PD (2002) Critical care management of head trauma in children. Crit Care Med 30(11 SUPPL):S393-S401
4. Mazzola CA, Adelson PD (2002) The ABCs of pediatric head trauma. Semin Neurosurg 13(1):29-37

5. Bell MJ, Kochanek PM (2013) Pediatric traumatic brain injury in 2012. The year with new guidelines and common data elements. Crit Care Clin 29(2):223-238

6. McPherson C, Haslam M, Pineda R, Rogers C, Neil JJ, Inder TE (2015) Brain injury and development in preterm infants exposed to fentanyl. Ann Pharmacother 49(12):1291-1297

7. Ikonomidou C (2011) Triggers of cell death in the developing brain. Curr Pediatr Rev 7(4):293-300

8. Olsen EA, Brambrink AM (2013) Anesthesia for the young child undergoing ambulatory procedures: current concerns regarding harm to the developing brain. Curr Opin Anaesthesiol 26(6):677684

9. Hammarlund-Udenaes M, Paalzow LK, de Lange EC (1997) Drug equilibration across the blood-brain barrier-pharmacokinetic considerations based on the microdialysis method. Pharm Res 14(2): 128-134

10. Le Roux P, Menon DK, Citerio G, Vespa P, Bader MK, Brophy G et al (2014) The international multidisciplinary consensus conference on multimodality monitoring in neurocritical care: evidentiary tables: a statement for healthcare professionals from the Neurocritical Care Society and the European Society of Intensive Care Medicine. Neurocrit Care 21(Suppl 2):S297-S361

11. Yamamoto Y, Danhof M, de Lange EC (2017) Microdialysis: the key to physiologically based model prediction of human CNS target site concentrations. AAPS J

12. Guilliams K, Wainwright MS (2016) Pathophysiology and management of moderate and severe traumatic brain injury in children. $\mathrm{J}$ Child Neurol 31(1):35-45

13. Huh JW, Raghupathi R (2009) New concepts in treatment of pediatric traumatic brain injury. Anesthesiol Clin 27(2):213-240

14. Mtaweh H, Bell MJ. Management of pediatric traumatic brain injury. Curr Treat Options Neurol. 2015;17(5)

15. Kochanek PM, Carney N, Adelson PD, Ashwal S, Bell MJ, Bratton $\mathrm{S}$ et al (2012) Chapter 15. Analgesics, sedatives, and neuromuscular blockade. Pediatr Crit Care Med 13(1):S64-SS7

16. Dean NP, Boslaugh S, Adelson PD, Pineda JA, Leonard JR (2007) Physician agreement with evidence-based recommendations for the treatment of severe traumatic brain injury in children. J Neurosurg 107(5 Suppl):387-391

17. Mencía S, Botrán M, López-Herce J, Del Castillo J, Álvarez P, Ballestero Y et al (2011) Sedative, analgesic and muscle relaxant management in Spanish paediatric intensive care units. An Pediatr 74(6):396-404

18. Bar-Joseph G, Guilburd Y, Tamir A, Guilburd JN (2009) Effectiveness of ketamine in decreasing intracranial pressure in children with intracranial hypertension: clinical article. J Neursurg Pediatr. 4(1):40-46

19. German JW, Aneja R, Heard C, Dias M (2000) Continuous remifentanil for pediatric neurosurgery patients. Pediatr Neurosurg 33(5):227-229

20. Hungerford J, Tobias J, O'Brien N (2014) Sedation for children with moderate to severe TBI: remifentanil. Crit Care Med 42(12):A1519

21. Tobias JD (2008) Bradycardia during dexmedetomidine and therapeutic hypothermia. J Intensive Care Med 23(6):403-408

22. Hu CF, Fan HC, Chang CF, Chen SJ (2013) Current approaches to the treatment of head injury in children. Pediatr Neonatol 54(2):7381

23. Mellion SA, Bennett KS, Ellsworth GL, Moore K, Riva-Cambrin J, Metzger RR et al (2013) High-dose barbiturates for refractory intracranial hypertension in children with severe traumatic brain injury. Pediatr Crit Care Med 14(3):239-247

24. Russo H, Bressolle F, Duboin MP (1997) Pharmacokinetics of high-dose thiopental in pediatric patients with increased intracranial pressure. Ther Drug Monit 19(1):63-70 
25. Welch TP, Wallendorf MJ, Kharasch ED, Leonard JR, Doctor A, Pineda JA (2016) Fentanyl and midazolam are ineffective in reducing episodic intracranial hypertension in severe pediatric traumatic brain injury. Crit Care Med 44(4):809-818

26. Bar-Joseph G, Guilburd Y, Guilburd J (2009) Ketamine effectively prevents intracranial pressure elevations during endotracheal suctioning and other distressing interventions in patients with severe traumatic brain injury. Crit Care Med 37(12):A402

27. Ben Yehuda Y, Watemberg N (2006) Ketamine increases opening cerebrospinal pressure in children undergoing lumbar puncture. $\mathrm{J}$ Child Neurol 21(6):441-443

28. Gibbs JM (1972) The effect of intravenous ketamine on cerebrospinal fluid pressure. Br J Anaesth 44(12):1298-1302

29. Wyte SR, Shapiro HM, Turner P, Harris AB (1972) Ketamineinduced intracranial hypertension. Anesthesiology 36(2):174-176

30. Bourgoin A, Albanèse J, Wereszczynski N, Charbit M, Vialet R, Martin C (2003) Safety of sedation with ketamine in severe head injury patients: comparison with sufentanil. Crit Care Med 31(3):711-717

31. Karabinis A, Mandragos K, Stergiopoulos S, Komnos A, Soukup J, Speelberg B et al (2004) Safety and efficacy of analgesia-based sedation with remifentanil versus standard hypnotic-based regimens in intensive care unit patients with brain injuries: a randomised, controlled trial [ISRCTN50308308]. Crit Care 8(4): R268-R280

32. Pittman T, Bucholz R, Williams D (1989) Efficacy of barbiturates in the treatment of resistant intracranial hypertension in severely head-injured children. Pediatr Neurosci 15(1):1317

33. Hayden JC, Breatnach C, Doherty DR, Healy M, Howlett MM, Gallagher PJ et al (2016) Efficacy of alpha2-agonists for sedation in pediatric critical care: a systematic review. Pediatr Crit Care Med 17(2):e66-e75

34. Adelson PD, Bratton SL, Carney NA, Chesnut RM, du Coudray HE, Goldstein B et al (2003) Guidelines for the acute medical management of severe traumatic brain injury in infants, children, and adolescents. Chapter 9. Use of sedation and neuromuscular blockade in the treatment of severe pediatric traumatic brain injury. Pediatr Crit Care Med 4(3 Suppl):S34-S37

35. Pineda JA, Wallendorf M, Kharasch E, Doctor A, Welch TP (2012) Clinical effectiveness of fentanyl and midazolam for intracranial hypertension in pediatric traumatic brain injury. $\mathrm{J}$ Neurotrauma 29(10):A195-A1A6

36. Knuttgen D, Doehn M, Eymer D, Muller MR (1989) Fentanylinduced increase in intracranial pressure. Anaesthesist 38(2):73-75

37. Sabsovich I, Rehman Z, Yunen J, Coritsidis G (2007) Propofol infusion syndrome: a case of increasing morbidity with traumatic brain injury. Am J Crit Care 16(1):82-85

38. Cannon ML, Glazier SS, Bauman LA (2001) Metabolic acidosis, rhabdomyolysis, and cardiovascular collapse after prolonged propofol infusion. J Neurosurg 95(6):1053-1056

39. Bustos BR (2013) Continuous propofol infusion in neurocritical children. Intensive Care Med 39:S123

40. Vandenbrande J (2015) Short-term propofol infusion syndrome (PRIS): fact or fiction? A systematic review on early PRIS in intensive care and anesthesia. Crit Care 19:S168

41. Analgesics, sedatives, and neuromuscular blockade. Pediatr Crit Care Med. 2012;13(1 SUPPL.):S64-S7

42. Sebastiani A, Ditter A, Schaefer M, Werner C, Engelhard K, Thal S (2012) Posttraumatic induction of anesthesia with propofol enhances secondary brain damage in adult mice. J Neurosurg Anesthesiol 24(4):494

43. Bramwell KJ, Haizlip J, Pribble C, VanDerHeyden TC, Witte M (2006) The effect of etomidate on intracranial pressure and systemic blood pressure in pediatric patients with severe traumatic brain injury. Pediatr Emerg Care 22(2):90-93
44. Neil MJE, Dale MC (2009) Hypokalaemia with severe rebound hyperkalaemia after therapeutic barbiturate coma. Anesth Analg 108(6):1867-1868

45. Erkonen G, Lamb F, Tobias JD (2008) High-dose dexmedetomidine-induced hypertension in a child with traumatic brain injury. Neurocrit Care 9(3):366-369

46. Kotter T, da Costa BR, Fassler M, Blozik E, Linde K, Juni P et al (2015) Metamizole-associated adverse events: a systematic review and meta-analysis. PLoS One 10(4):e0122918

47. de Nadal M, Ausina A, Sahuquillo J, Pedraza S, Garnacho A, Gancedo VA (1998) Effects on intracranial pressure of fentanyl in severe head injured patients. Acta Neurochir Suppl 71:10-12

48. Shein SL, Ferguson NM, Kochanek PM, Bayir H, Clark RSB, Fink EL et al (2016) Effectiveness of pharmacological therapies for intracranial hypertension in children with severe traumatic brain injury-results from an automated data collection system timesynched to drug administration. Pediatr Crit Care Med 17(3):236245

49. Hertle DN, Dreier JP, Woitzik J, Hartings JA, Bullock R, Okonkwo DO et al (2012) Effect of analgesics and sedatives on the occurrence of spreading depolarizations accompanying acute brain injury. Brain 135(Pt 8):2390-2398

50. Marsot A, Goirand F, Milesi N, Dumas M, Boulamery A, Simon N (2013) Interaction of thiopental with esomeprazole in critically ill patients. Eur J Clin Pharmacol 69(9):1667-1672

51. Waalwijk-Van Den Heuvel NP, Van Dijk M, Buysse CMP, Tibboel D, Hunfeld MAW, Ista E, et al. Waking up children with traumatic brain injury (TBI): what causes the agitation? Eur J Pediatr. 2016;175(11):1448

52. Harris J, Ramelet AS, van Dijk M, Pokorna P, Wielenga J, Tume L et al (2016) Clinical recommendations for pain, sedation, withdrawal and delirium assessment in critically ill infants and children: an ESPNIC position statement for healthcare professionals. Intensive Care Med 42:972-986

53. Amigoni A, Mondardini MC, Vittadello I, Zaglia F, Rossetti E, Vitale F et al (2017) Withdrawal assessment tool-1 monitoring in PICU: a multicenter study on iatrogenic withdrawal syndrome. Pediatr Crit Care Med 18(2):e86-e91

54. Sadhasivam S, Chidambaran V, Zhang X, Meller J, Esslinger H, Zhang K et al (2015) Opioid-induced respiratory depression: ABCB1 transporter pharmacogenetics. Pharmacogenomics J 15(2):119-126

55. Sadhasivam S, Chidambaran V, Esslinger H, Zhang X (2014) Genetic variants of blood brain transporter, $\mathrm{ABCB} 1$ are associated with opioid related respiratory depression in children. Anesth Analg 118(5):S271

56. Suárez PM, Ramos MVR, Camacho JDS, Lobato JE, Hoyos AM (2016) Opioid related neurotoxicity on pediatric population after general anesthesia. Rev Soc Esp Dolor 23(4):181-185

57. Morrison G, Fraser DD, Cepinskas G (2013) Mechanisms and consequences of acquired brain injury during development. Pathophysiology 20(1):49-57

58. Andropoulos DB, Greene MF (2017) Anesthesia and developing brains - implications of the FDA warning. N Engl J Med 376(10): 905-907

59. Yamamoto Y, Valitalo PA, van den Berg DJ, Hartman R, van den Brink W, Wong YC et al (2017) A generic multi-compartmental CNS distribution model structure for 9 drugs allows prediction of human brain target site concentrations. Pharm Res 34(2):333-351

60. De Cock RF, Piana C, Krekels EH, Danhof M, Allegaert K, Knibbe CA (2011) The role of population PK-PD modelling in paediatric clinical research. Eur J Clin Pharmacol 67(Suppl 1):5-16

61. Knibbe CA, Danhof M (2011) Individualized dosing regimens in children based on population PKPD modelling: are we ready for it? Int J Pharm 415(1-2):9-14 